\title{
Linguagem dos ritos
}

\author{
The language of rites
}

Carmen Junqueira

\begin{abstract}
Resumo
$\mathrm{O}$ artigo trata do conjunto de rituais que ocorrem quando do falecimento de um membro da comunidade kamaiurá de Ipavu e que culminam com a realização da maior cerimônia intertribal no alto rio Xingu (MT), o Kuaryp. Numa primeira etapa, são apresentados os ritos fúnebres dos quais participam a família enlutada e os moradores da aldeia, numa sequência de atos que revelam a reciprocidade na prestação de trabalho, favores, e oferta de bens. O luto é aos poucos aliviado até a realização da grande festa, quando então é finalmente retirado.
\end{abstract}

Palavras-chave: Mitos. Ritos. Cerimônia Intertribal. Luto. Comunidade Indígena.

\begin{abstract}
The article deals with a body of rituals that take place when a member of the Kamaiurá Ipavu community dies. These rituals culminate with the greatest intertribal ceremony of the Upper Xingu (state of Mato Grosso, Brazil), Kwaryp. Funeral rituals with the participation of the family in mourning and the villagers are presented first in a sequence of acts that reveal the reciprocity as regards services, favors and goods. The mourning gradually weakens until a major celebration that puts a definite end to it.
\end{abstract}

Keywords: Myths. Rites. Intertribal Ceremony. Mourning. Native American Community.

$\mathrm{Na}$ Antropologia costuma-se definir rito como um tipo de cerimônia, cujo objetivo principal é fazer uso de determinadas maneiras de agir, de proferir palavras específicas, realizar gestos ou exibir símbolos que produzem os resultados desejados. A festa do Kwaryp ${ }^{l}$ na forma como é realizada na aldeia kamaiurá de Ipavu exibe do começo ao fim uma considerável sequência de rituais, muitos dos quais podem passar despercebidos, tão discreta é sua execução. O significado de cada um deles nem sempre é de fácil apreensão,

\footnotetext{
${ }^{1} A$ cerimônia do Kwaryp é bastante citada em textos etnológicos, sendo, entretanto, poucos os trabalhos que oferecem uma visão geral de toda a sequência ritual. Estudos bem mais completos são: Kwarìp, mito e ritual no Alto Xingu, de Pedro Agostinho (1974) e O Kwaryp kamaiurá na aldeia de Ipavu, de Carmen Junqueira e Vaneska Taciana Vitti (2009)
} 
havendo inclusive alguns cujo propósito já escapou da memória do povo e são realizados em diferentes momentos "porque sempre foi assim", dizem os Kamaiurá.

O objetivo deste texto é expor alguns rituais ${ }^{2}$, comentar seus propósitos mais acessíveis e tentar analisar de modo mais detido o conteúdo de um deles. A tarefa não é fácil e requer uma acentuada vigilância a fim de evitar que a lógica do nosso modo de pensar se infiltre na explicitação do significado. A principal regra é não trabalhar com deduções estranhas ao universo das significações indígenas, procurando permanecer rente à própria lógica do pensamento kamaiurá, presente na sua vasta produção de narrativas míticas, tanto as que eu mesma coletei desde os anos finais da década de 1960, como as disponíveis nas publicações sobre a cultura kamaiurá ${ }^{3}$.

O Kwaryp é uma rememoração de dois atos ancestrais realizados por Mavutsinin: a criação da humanidade e o esforço para ressuscitar os mortos. Foi ele também quem distribuiu aos povos alto-xinguanos os principais símbolos da sua identidade, conquistou o dia com a ajuda dos dois netos, os gêmeos Kwat e Iay, livrando suas criaturas da escuridão sem fim, legou conhecimentos sobre os espíritos das matas, das águas e dos céus, e seus poderes de cura.

O primeiro ato ancestral ocorreu em Morená, local situado no baixo rio Culuene, próximo da junção com o rio Xingu. Era em Morená a morada de Mavutsinin e nas areias da praia ele fincou toras de madeira, tirou-lhes a casca com cuidado, pintou-os e adornou-os com cocar, penas, cintos, colares de tal forma que exibissem uma imagem fiel do que seria sua criação. Mavutsinin e a cutia cantaram durante horas, pontuando o ritmo com o chocalhar dos maracás. Horas depois foram lentamente surgindo os braços, as pernas, a figura do corpo se delineou com clareza para então surgir a cabeça em cada um dos postes. Estava criado o homem. Toda a natureza entrou em festa. Peixes saíram d'água e dançaram na areia branca, aos pulos e gritos de alegria. As onças saíram da mata e, enfurecidas com a algazarra, se atracaram com os peixes. Mavutsinin irritado com o barulho fez tudo cessar ao proclamar: meus filhos criados do tronco serão morerekwat e vocês, peixes e onças, kamara. (Villas Bôas 2000:77-78) A narrativa, coletada nos primeiros anos de contato com os Kamaiurá, não é mais lembrada nem mesmo pelos narradores mais velhos, embora a divisão social permaneça, reservando aos morerekwat lugar de destaque no Kwaryp.

Concretizada a criação, foi necessário dotar cada um dos homens com um símbolo da sua humanidade. Mavutsinin apresentou-lhes então uma série de bens para que escolhessem o que mais os atraísse: panela de cerâmica, arco de madeira preta, colar de placas de caramujo, cinto de discos de caramujo etc. Os

\footnotetext{
${ }^{2}$ Uma versão preliminar deste texto foi publicado em 2009 (Junqueira e Vitti 2009).

${ }^{3}$ Sobre mitologia kamaiurá consultar: Agostinho (1974); Samain (980); Seki (2010); Villas Bôas (1970, 1986, 1992, 2000); Würker e Troncarelli, (2005).
} 
Kamaiurá pegaram o arco preto, os Waurá, a panela e os Kuikuro e Kalapalo as peças de caramujo. Em 1965, o caraíba (o não-índio) já tinha sido incluído na criação, tendo escolhido a carabina como símbolo da sua humanidade, motivo pelo qual o criador mandou-o para bem longe. "Só agora ele está voltando para cá", comentavam os Kamaiurá.

O segundo ato ancestral, do qual há diferentes versões, teve lugar quando, com o passar do tempo, Mavutsinin constatou que os seres humanos morriam. Decidiu realizar um novo Kwaryp semelhante ao primeiro, mandando que todos da aldeia se fechassem em suas casas. Pintou e enfeitou as toras de madeira e depois de cantar por horas a fio os mortos tornaram a ter vida. Os homens da aldeia foram convidados a deixar suas casas e apreciar o resultado do empenho do criador e do poder dos cantos e maracás sagrados. Entretanto, não deveriam deixar suas casas aqueles que tivessem tido relações sexuais à noite. Só um homem permaneceu fechado na casa, mas vencido pela curiosidade resolver espiar o grande acontecimento. No mesmo instante, os ressuscitados voltaram a ser simples toras de madeira. Não havia nada mais a fazer e Mavutsinin falou: "de agora em diante, o Kwaryp será realizado apenas para homenagear os mortos, não há mais como fazê-los reviver". Com isso, todos aprenderam o perigo que advém das transgressões rituais.

Todos os kamaiurá após a morte - homens, mulheres, crianças, adultos e velhos - devem ser homenageados na cerimônia do Kwaryp, mas depois dos primeiros ritos fúnebres, apenas os homens morerekwat e as mulheres nuitu podem dar permissão para o prosseguimento da sequência ritual que prosseguirá até a grande festa de encerramento.

O processo se desenvolve da seguinte forma:

A primeira fase tem início logo após o falecimento da pessoa e trata especialmente dos cuidados relativos ao corpo do morto e seu sepultamento ${ }^{4}$.

A segunda fase ocorre várias semanas após a morte, quando os enlutados são instados a definir se desejam ou não o prosseguimento dos rituais. A decisão tem como ponto central a construção de uma cerca baixa de madeira (apenap) ao redor da sepultura e o consentimento significa que os enlutados concordam com a futura realização da festa do Kwaryp.

A terceira e última fase tem início quando as Plêiades podem ser vistas na linha do horizonte, anunciando tempo seco, dias quentes, noites frescas e águas propícias à pesca. Em algum momento dos meses de julho, agosto ou setembro intensificam-se os preparativos para a cerimônia do Kwaryp. (Junqueira e Vitti 2009:137)

${ }^{4}$ A descrição dessa fase baseia-se em depoimentos, uma vez que nunca chegamos a observála pessoalmente. 
Logo após o falecimento de um morerekwat ou de uma nuitu, seis homens da aldeia que não tenham parentesco próximo com a família enlutada formam uma equipe, liderada por um deles, que cuidará de cavar a sepultura e preparar o corpo do morto. Têm assim início os ritos fúnebres e a primeira tarefa do líder é seguir até à casa dos enlutados pedir permissão para fazer a sepultura. A dor da perda é grande e os parentes do morto se negam a admitir seu sepultamento. Somente depois da terceira tentativa, a família dá seu consentimento, designando um dos seus membros para ser o "dono do morto" (umanõjat), isto é, a pessoa que irá representar os enlutados e que terá daí em diante papel destacado nos demais rituais. Cabe ao "dono do morto" comunicar à equipe de "sepultadores" (ywywaraiokat), por meio do seu líder, a decisão de permitir a abertura da cova.

Todos os mortos são enterrados no pátio da aldeia, em local próximo do tapyyj, que é a casa dos homens. À medida que aumenta o número de falecimentos na aldeia, as sepulturas se distribuem a maior distância, mas, como regra, reservase aos morerekwat e às nuitu os locais mais próximos dessa casa. Natimortos e nenês muito novinhos são enterrados dentro da casa da família. Pessoa acusada de feitiçaria e executada na aldeia tem seu corpo jogado em qualquer canto, cabendo à sua família enterrá-lo fora do pátio central.

São quatro as modalidades de enterramento: em posição fetal (omoapikawa) ou "sentado", como dizem; em pé (wyrareheiami), sendo a rede que envolve o corpo atada a uma armação de madeira; deitado na cova (ywypinue), e com o corpo suspenso (mokoin wykwat) quando é cavado um túnel com duas aberturas através das quais são fixadas duas estacas no solo, nas quais a rede com o corpo é amarrada, sem tocar o chão.

Os "sepultadores" se dividem, indo alguns cuidar da abertura da sepultura enquanto os demais pedem permissão ao "dono do morto" para banhar o corpo, pintá-lo e adorná-lo. Se a pessoa morta for do sexo feminino, as esposas dos "sepultadores" farão a tarefa. Dentro da rede do homem são colocados um arco e flechas e na da mulher, seu fuso de fiar algodão. Tanto arco e flechas são armas essenciais para a alma se defender dos ataques dos pássaros súditos do urubu real, e com o mesmo propósito a alma da mulher constrói armadilhas com os fios de algodão saídos do seu fuso.

Assim que termina a preparação do corpo ocorre uma outra etapa do rito fúnebre e cabe novamente ao líder dos "sepultadores" pedir permissão ao "dono do morto" para levar o corpo. Para os enlutados esse é o momento mais difícil de ser enfrentado, pois o morto ao ser levado, apartado de todos desaparecerá para sempre. Ao primeiro e segundo pedidos para levar o corpo, o "dono do morto" nega a permissão. Após alguma espera, pacientemente, é feita uma terceira solicitação, que é então atendida. O morto, que repousa dentro da rede costurada, é colocado numa estrutura de madeira para facilitar sua remoção. O ritual da saída é complexo e não é possível compreender concretamente seu significado: 
O corpo é então carregado pela porta dos fundos, dá uma volta pelo lado esquerdo da casa e nela entra novamente; sai outra vez pela porta dos fundos, contorna a casa pelo lado direito e torna a entrar. Finalmente o cortejo dá uma volta no centro da casa e sai pela porta da frente em direção à sepultura, sempre acompanhado pelo canto do pajé. Contorna-se a sepultura e, em seguida, coloca-se o morto, com o rosto voltado para o nascente. O corpo é protegido com esteiras e na cabeça leva uma panela de cerâmica, trazida pelos familiares. Só então a sepultura é coberta com terra. (Junqueira e Vitti 2009:138)

É possível que o trajeto do cortejo, antes de se dirigir à sepultura, tenha intenção de levar o morto pela última vez às partes externas da casa, local onde as mulheres trabalham, as crianças menores brincam; a última volta na parte central do interior da casa, poderia ser um último olhar à área destinada ao convívio social onde também se localiza a fogueira sobre a qual é preparada a alimentação cotidiana. Seria enfim o último adeus. Depois do corpo descer à sepultura, tenta-se impedir que ele venha a ter contato direto com a terra, as esteiras servindo-lhe de anteparo. A panela sobre a cabeça significa uma proteção adicional à integridade da alma quando dos ataques das aves, pois as bicadas visam sua cabeça, parte mais apetitosa da alma aguardada pelo urubu real. A cabeça é também o local vital da alma que se muito atingido pode levala à morte.

Ao final do enterro, o líder dos "sepultadores" convoca o "dono do morto" e seus familiares para um banho ritual, sobre a sepultura, cujo significado é limpar, remover as lágrimas choradas. Por três dias consecutivos a família enlutada faz uma fogueira sobre a sepultura para que a alma do morto encontre o caminho que o levará à aldeia dos mortos. Caso a alma insista em permanecer na casa em que sempre habitou, um pajé procederá ao ritual de expulsão.

A aldeia das almas está situada em algum lugar dentro do território circunvizinho e nela a vida gira em torno de festas, danças e dos alimentos sempre fartos. A alma dos animais domésticos faz companhia à alma dos seus donos. Cada povo tem sua aldeia das almas da mesma forma que os demais animais da mata, da água, dos ares. Dizem que a alma dos morerekwat e das nuitu come tucanaré, matrinxã e outros peixes de primeira, enquanto a alma dos kamara se alimenta de grilos e baratas, segura de estar comendo os melhores peixes. As almas, de modo geral, são bastante frágeis, ingênuas e mesmo medrosas. Há uma narrativa mítica muito bonita que conta a história de um rapaz que chorava à beira da lagoa a morte do seu melhor amigo e que de repente ouve ruído de vozes. Ele se esconde e vê passar um séquito de almas que seguia para a Via Láctea a fim de chegar ao céu e participar da festa dos pássaros, que é de fato uma batalha mortal entre almas humanas e pássaros. O confronto ocorre quando 
há eclipses. Cabe às almas se defenderem atirando flechas ou aprisionando os pássaros em armadilhas de fio de algodão.

O jovem rapaz observava tudo, até que ouviu quando uma das almas comentou: "que cheiro de gente viva", seguramente se referindo a ele. Escondeu-se o quanto pode, mas a última alma da fila era a do seu amigo, que logo o avistou. Os dois se abraçaram e o morto convidou-o a acompanhar o cortejo até o campo inimigo. Sua presença foi de grande valia, pois logo adiante encontraram um terreno forrado de espinhos. As almas ficaram apavoradas, temendo se ferir e morrer; foi preciso que o rapaz limpasse o solo para que a caminhada prosseguisse. Mais adiante toparam com solo alagado cheio de caranguejo. As almas entraram novamente em pânico. $\mathrm{O}$ rapaz foi à frente esmagando alguns deles para que passassem. A noite chegou e o grupo resolveu dormir, cada qual em sua rede. O rapaz teve de dormir com a alma do amigo, pois não tinha trazido rede. Antes de dormirem, a alma lhe falou: não tenha medo de mim. Apesar de não entender muito bem o que a alma queria dizer, o rapaz concordou. Durante a noite ele acordou e na rede estava uma enorme cobra! Imediatamente ele virou a rede para se livrar do bicho que ao atingir o chão se transformou na alma do amigo! É que as almas viram cobra quando dormem para não serem comidas pelos pássaros. A maioria dos pássaros e passarinhos teme as cobras. Finalmente, chegaram ao céu, onde fica a aldeia dos pássaros comandada pelo urubu rei e sua corte composta pelo falcão, pela águia e outras aves de rapina de grande porte. Em pouco tempo já estavam todos no campo de batalha. Os pássaros vinham em grande velocidade e arrancavam nacos da cabeça das pobres almas, levando-os para o chefe. As almas também acertavam muitos deles e a matança era geral, com vantagem para os pássaros. A presença do rapaz fez a diferença, pois sem temê-los valeu-se de paus, pedras e, principalmente, dos urros que soltava assustando a passarada. Os pássaros começaram a ser mortos em quantidade, mesmo porque aturdidos tornavam-se alvos fáceis, até que o comando maior mandou que eles se retirassem. As almas sobreviventes voltaram para sua aldeia na terra e o rapaz para sua casa. Lá ele ensinou o povo como se comportar durante os eclipses: gritar, tocar flauta, sempre muito alto para assim ajudar as almas a sobreviver.

Como foi dito, na aldeia kamaiurá, a alma renitente precisa ser expulsa para que se junte à sociedade dos mortos. A partir de então, seus familiares experimentam de modo ainda mais doloroso sensação de solidão que o luto acarreta, passando dias e dias sem trocar palavra, pouco se alimentam e sentemse sem rumo. A aldeia como um todo entende a dor que sofrem e também entra em luto. Crianças deixam de brincar pelo pátio, não se fala alto, ninguém ri, rádios são desligados e a escola fecha as portas. Dez ou quinze dias após o enterro o líder dos "sepultadores" pergunta ao "dono do morto" se o luto da aldeia pode ser aliviado e pouco a pouco a vida retoma o ritmo usual.

Quando a pesada sombra de morte esmaece, o líder "sepultador" pergunta 
ao "dono do morto" se os homens podem sair para a pescaria, após a qual os enlutados devem proceder à distribuição dos peixes com beiju a toda a aldeia. A partir de então, destaca-se de modo claro o ciclo de prestação e distribuição presentes no Kwaryp, em perfeita sintonia com o fenômeno estudado por Mauss e por ele conceituado como fato social total, que exprime

[...] ao mesmo tempo e a uma só vez, toda espécie de instituições: religiosas, jurídicas e morais - estas políticas e familiais ao mesmo tempo; econômicas - supondo formas particulares de produção e de consumo, ou antes, de prestação e de distribuição, sem contar os fenômenos estéticos nos quais desembocam tais fatos e os fenômenos morfológicos que manifestam essas instituições. (Mauss 1974: 41)

Uma característica importante do fenômeno da oferta e retribuição de bens materiais, presentes, serviços, entre outros, é sua aparência voluntária, que pode enganosamente ser entendida como fruto da generosidade, mas que é, no entanto, um ato imposto e interessado. (Mauss 1974: 41) A circulação de bens e gentilezas que sempre pressupõe a reciprocidade é segundo Mauss "apenas um termo de um contrato muito mais geral e muito mais permanente. (Mauss, idem: 45)

No caso Kamaiurá observa-se que o fenômeno expressa a criação e a manutenção de vínculos sociais e visa, entre outras coisas, o fortalecimento das relações entre as famílias da comunidade e entre os diferentes povos altoxinguanos. A reciprocidade envolvida na circulação dessas dádivas, ou dons como diz Mauss, independe de simpatias ou antipatias pessoais, pois é executada de acordo com uma rígida etiqueta que permite ampliar a colaboração. Mauss diz claramente que não se trata de relações entre indivíduos,

[...] e sim coletividades que se obrigam mutuamente, trocam e contratam; as pessoas presentes ao contrato são pessoas morais - clãs, tribos, famílias - que se enfrentam e se opõem, seja em grupos, face a face, seja por intermédio dos seus chefes, ou seja ainda das duas formas ao mesmo tempo. (Mauss, idem, ibdem)

Deixar de retribuir qualquer uma dessas obrigações implica em rompimento do vínculo social e, provavelmente em outros tempos, poderia levar ao acúmulo de tensão e, ao final, a uma declaração de guerra. A contribuição de Mauss ajuda a entender não apenas a distribuição de peixes à comunidade realizada pelo "dono do morto" e seus familiares, mas igualmente lança luz sobre outros rituais que se sucedem.

O propósito da pescaria é fazer com que os enlutados possam retribuir à comunidade o respeito demonstrado à dor que sofreram. Com a ocorrência da morte, a aldeia como um todo guardou luto, reconhecendo a dolorosa perda sofrida pela família. Ao mesmo tempo, a pescaria coloca os enlutados frente 
a tarefas práticas como recolher madeira para construir jiraus e acomodar os peixes e depois proceder à sua distribuição É de certa forma uma chamada à realidade da vida na aldeia, um primeiro afastamento da reclusão a que a família enlutada se impôs.

Vê-se que no seu conjunto o Kwaryp faz do bem sucedido mito da criação, e da fracassada cerimônia da ressuscitação a explicação do porquê do nascimento e morte dos seres humanos, e sobre esse pano de fundo pontua uma sequência de rituais que obriga os enlutados a participar publicamente. Sabem os Kamaiurá que a dor do luto chega num só golpe, mas sua superação só pode ser conquistada por etapas. Os ritos fúnebres e demais rituais se constituem em tais etapas que, pouco a pouco, estimulam os enlutados a reagir, aliviam a dor da perda e permitem a eles reencontrar o caminho de suas vidas.

Antes da distribuição dos peixes tem lugar uma sequência de ritos:

1. No pátio central da aldeia ocorre a cerimônia do corte do cabelo dos enlutados. Os homens têm o cabelo aparado apenas na nuca, e as mulheres em torno de toda a cabeça.

2. Em seguida, vem o banho ritual desses familiares, sobre a sepultura, ao mesmo tempo em que os cantadores (maraka'ip) entoam cantos.

3. Os "sepultadores" pintam o cabelo dos homens enlutados com o vermelho do urucum, colocam em seus quadris uma faixa de fio de algodão (kwahap) e em cada orelha uma pena amarela.

4. O "dono do "morto" e seus familiares banham, pintam e colocam nos "sepultadores" adornos semelhantes aos que receberam.

5. Ao final, as esposas dos "sepultadores" e a esposa do "dono do morto" banham os moradores da comunidade sobre a sepultura e pintam todos eles.

6. A comunidade, no exercício da reciprocidade, leva ao "dono do morto" e seus familiares, dádivas em retribuição à pintura que receberam.

Finalmente, os peixes envoltos em beiju são levados para frente da casa dos homens (tapyyj), local que designam como "o centro", e são distribuídos aos donos das unidades residenciais.

Os sucessivos rituais do banho junto à sepultura têm por finalidade lavar a lembrança do parente morto, aliviar o sofrimento, estimular o esquecimento. A retirada do luto irá coincidir com um último banho. A morte é um evento social que comove toda a comunidade e que ao mesmo tempo propicia o estreitamento dos vínculos interfamiliares e intertribais. 
A aldeia retoma suas atividades rotineiras e os "sepultadores" mantêmse atentos aos sinais da natureza. "Com a lua nova no oeste", como dizem, o líder dos sepultadores, em comum acordo com seus liderados, vai ao "dono do morto" perguntar se pode iniciar a colocação do apenap. Trata-se de uma cerca feita com pequenas toras de madeira fincadas ao redor da sepultura, que lembra o formado de um retângulo com as duas linhas menores curvadas para seu interior. Construir o apenap significa dar andamento a uma série de providências que irão terminar com a realização da cerimônia do Kwaryp.

Antes de concordar com a construção do apenap os enlutados precisam avaliar se tem condições de produzir a quantidade necessária de polvilho para fazer frente à generosa distribuição de beiju que acompanha os peixes a serem oferecidos aos convidados para o Kwaryp. Como regra, todos os povos do alto Xingu são convidados, o que significa 2.844 pessoas. Subtraindo desse total a população kamaiurá da aldeia de Ipavu, que é de 351 indivíduos, tem-se 2.493. Se $10 \%$ comparecerem à festa, tem-se um total de 249 pessoas. Adicione-se a isso os habitantes da aldeia kamaiurá de Ipavu que também recebem alimento e vê-se que a cifra se eleva para 600 bocas a serem alimentadas ${ }^{5}$. Os enlutados precisam ainda verificar se conseguem estocar uma quantidade grande da castanha de pequi, cujo fruto amadurece no início da estação das chuvas, por volta de outubro, quando então é possível extrair a castanha a ser distribuída aos líderes das aldeias convidadas. Além do próprio esforço, os enlutados esperam contar com a colaboração de parentes e amigos, e de famílias da categoria social kamara que queiram aproveitar a oportunidade para homenagear seus mortos. Pois, como foi visto anteriormente, todos os mortos devem ser homenageados no Kwaryp , muito embora a cerimônia só se realize quando da morte de pessoas da categoria morerekwat/muitu.

Caso os enlutados autorizem a construção da cerca baixa denominada apenap que delimita a sepultura do morto principal, instaura-se na aldeia um clima festivo que contrasta com o luto que todos guardaram em sinal de respeito à dor da família enlutada e a atitude reservada que se seguiu quando o luto da aldeia foi aliviado. Embora a família do morto se mantenha recolhida, o clima na aldeia é de festa. De alguma maneira é intrigante a rápida passagem de um período de recato a uma alegria contagiante. Uma possível explicação seria a confirmação da grande festa do Kwaryp, que iria quebrar a rotina cotidiana, instaurando uma ocasião de muito movimento, reencontros, desafios na luta huka huka conjugados com a consagração de novos grandes lutadores e, também, a fartura de comida. De certa forma, alinhando-se ao contentamento de todos, o "dono do morto" passa a ser chamado de "dono da festa" (torypajat) ou simplesmente "dono" (jajat), e os "sepultadores" "donos da fala" (je'enjaret), por terem proferido o discurso solicitando a construção do apenap.

${ }^{5}$ Agradeço a Vaneska Taciana Vitti a atualização do número de habitantes do alto Xingu em 2013, assim como da aldeia kamaiurá de Ipavu. 
Os "donos da fala" providenciam o corte da madeira que no dia seguinte é solenemente levada para o pátio da aldeia, onde é cortada em pequenas toras, num ritual vetado às mulheres, que tem permissão apenas para assistir à fixação e amarração das toras em torno da sepultura do morto. À tardinha o "dono da festa" entrega maracás e bastões aos cantadores (maraka'yp) responsáveis pelos cantos rituais que se estendem por quase uma hora, Cessado o canto, os homens da aldeia adornados e pintados apresentam no pátio a "dança do Kwaryp" (morahãi). Ao final, cantadores e dançarinos recebem do "dono da festa" kauin, peixe assado e beiju. Segue-se o soar das grandes flautas uruá, tocadas por dois homens ricamente pintados e adornados, que percorrem o pátio central. Quando a noite se aproxima, os "donos da fala" lideram um grupo de mulheres que cantando se apresentam no pátio para finalmente entrar na casa do "dono da festa", de quem recebem peixe. Esse feixe de rituais realizados com a fixação do apenap é mais um passo à frente no sentido de mitigar o sofrimento dos enlutados.

O espaço de tempo entre o enterro e a cerimônia final do Kwaryp varia e pode mesmo demorar um ano ou mais. É na estação seca, em algum dia dos meses de julho, agosto ou setembro que se realiza a maior festa intertribal no alto Xingu. Assim que a data é definida, toras de madeira são cortadas para representar os mortos a serem homenageados, sendo o tronco mais grosso reservado para o morerekwat ou a nuitu e os ligeiramente mais finos, para os demais mortos. Todos eles ficam escondidos na mata, longe da vista das mulheres. O apenap que circundava a sepultura do morto de maior prestígio é retirado e suas pequenas toras são reduzidas a lenha para posterior utilização. Encerrando o ritual do corte dos trancos, dois cantadores (maraka 'ip) postamse à frente da sepultura, de costas para a casa dos homens (tapyyj), e munidos de maracás e bastões exibem seus cantos que são silenciados quando os homens chegam ao pátio para realizar a "dança do Kwaryp" (morahãi). No dia seguinte, os mesmos cantos e danças são repetidos.

$\mathrm{Na}$ sequência, organiza-se a grande pescaria $(\operatorname{Kwary}(p)$ apotap) com a participação de praticamente todos os homens da aldeia e algumas mulheres. Tão importante como a presença dos pescadores é a dos pajés responsáveis pelas rezas e rituais que asseguram o êxito da pescaria. Veta-se a presença de mulheres menstruadas ou de homens que tenham tido contato muito próximo com elas. A equipe acampa nas proximidades das lagoas Ywytatanip, Iratsimãi e Jenipavu, localizadas dentro do território kamaiurá e de uso exclusivo da comunidade de Ipavu. Ali são construídos vários jiraus para moquear os peixes, à medida que forem retirados da rede. Em seguida, os homens montam uma barreira na boca da primeira lagoa.

No dia seguinte, a rede é estendida na margem da lagoa e os pajés dão início aos rituais propiciatórios: fumam e cantam ao lado da rede e em seguida espalham sobre ela massa de mandioca para atrair os peixes. A rede é então estendida entre 
as duas margens, enquanto os pajés mais uma vez fumam, depois mergulham, emergem com as mãos fechadas e seguem em direção à margem onde enterram, num ato simbólico, o ferrão da arraia. O ritual é imprescindível para proteger os pescadores das arraias encobertas que ficam pela areia do fundo da lagoa e que, se pisadas, ferem com seu potente ferrão o pé, o calcanhar do pescador. Finalmente a rede é estendida até a barreira e alguns homens começam a bater o timbó na água entorpecendo os peixes. Quando a rede é puxada para a praia, as mulheres enchem suas bacias e voltam para o acampamento a fim de moquear os peixes. No fim do dia é hora de mais um ritual: os pajés entram na lagoa, cada qual carregando uma cabaça com mingau de pequi que oferecem ao espírito da arraia. Seguem então para o meio da lagoa onde fincam uma vara e amarram as cabaças vazias. Já na margem, fumam novamente para finalizar a oferenda. São procedimentos importantes que protegem os pescadores, garantem êxito na pescaria e agradam a bela Pira' $i$, espírito dos peixes, também designada "mãe dos peixes." Se a quantidade de peixe não for suficiente, na manhã seguinte segue-se para a lagoa Iratsimãi para nova captura, repetindo-se o ritual do enterramento do ferrão da arraia.

$\mathrm{Na}$ aldeia, os preparativos da festa se aceleram com a chegada dos peixes. Os enlutados são conduzidos ao pátio para tomar o banho da retirada do luto. Emissários (pareat) portando o convite formal para o Kwaryp são enviados às aldeias amigas. Em 1965, os convidadores, como costumam ser chamados, saiam a pé ou de canoa para alcançar a aldeia a ser convidada, com muita antecedência. Levavam consigo uma cordinha de fibra de tucum com vários nós, que significavam o número de noites a serem dormidas até o dia da festa, que entregavam ao cacique da aldeia. Atualmente, os pareat deixam a aldeia na véspera da festa. Tanto eles como os convidados se locomovem de moto, caminhão, barco a motor e também bicicleta. Cada aldeia convidada recebe os dois emissários de modo cerimonial: os viajantes param na entrada da aldeia e esperam que alguém venha conduzi-los ao pátio central, onde são acomodados em bancos, à espera do cacique. Este não vem de pronto, mas se enfeita com brincos, braçadeiras e, de fato, estica o tempo dos preparativos propositalmente, deixando os pareat expostos ao severo sol da estação seca por até uma hora. O encontro é conduzido por meio de discursos formais do cacique e demais líderes locais ${ }^{6}$.

No dia seguinte, os troncos de madeira representando cada um dos mortos homenageados são fixados defronte à casa dos homens e pintados num ritual interditado às mulheres. Seguem-se os cantos dos maraka'yp, e em seguida os enlutados chegam para adornar o poste do seu morto com cintos, cocares, colares e algodão, ao mesmo tempo em que lamentam e choram sua ausência. Ao fim, dois tocadores da flauta uruá saem da casa do "dono da festa", passam

${ }^{6}$ Samain (1980:80-85), registrou um discurso proferido nessas ocasiões. 
pela frente de todas as casas, marcando o ritmo com passadas pesadas. Ergue-se uma cobertura para proteger os troncos e em seguida tem início a pintura dos enlutados pelos parentes dos pareat. Sob essa cobertura e junto aos troncos, os parentes farão seus lamentos e irão chorar a noite toda.

O clima é de agitação, cada qual procurando enfeites e se esmerando para embelezar o corpo. Os lutadores aguardam ansiosos a chegada da competição e preparam-se para vencer: escarificam braços e pernas, se esmeram para aumentar o poder dos músculos, vão ao pajé para que reze junto a eles. Cantos entoados pelos maraka'yp ressoam em meio ao burburinho das providências, sendo intercalados pela "dança do kwaryp". A luta, denominada huka huka, que vai ocorrer no dia seguinte, passa a ser o momento mais esperado da festa, que é só alegria. Apenas os familiares dos mortos seguem chorosos e retraídos.

À tardinha, começam a chegar os convidados tendo à frente o líder da aldeia. Param na estrada que leva ao pátio e aguardam a chegada do pareat que os convidou e que certamente limpou o terreno onde deverão acampar. A cena se repete com os demais convidados das diferentes aldeias alto xinguanas. $\grave{A}$ noite, o pareat vai ao acampamento para guiar os líderes da aldeia e acomodalos em bancos à pequena distância dos troncos ornados, quando lhes é oferecido mais uma vez alimento: beiju e peixe. Os lutadores kamaiurá vem ao pátio para saudá-los e executam a dança ho'at (expressão que designa aproximadamente "grupo reunido", "coeso"): com grande agitação circundam os líderes e os troncos, entoando em uníssono um grito marcial e em seguida se dispersam. $\mathrm{O}$ entusiasmo guerreiro toma conta da aldeia. Os lutadores de todas as aldeias convidadas, cada qual no seu momento, entram no pátio e repetem a mesma coreografia dos anfitriões, em seguida pegam achas de lenha das fogueiras que ardem defronte os troncos e retornam ao acampamento para alimentar a própria fogueira. Após a demonstração guerreira, os líderes se retiram, abrindo espaço para os líderes da próxima aldeia visitante.

Iniciam-se então os cantos de dois maraka'yp kamaiurá. Em seguida, as aldeias convidadas exibem seus melhores cantores numa apresentação que não esconde o caráter competitivo, num desfilar de vozes extraordinárias. Após a apresentação, cada par de cantores recebe peixe e beiju dos anfitriões. Enquanto tudo isso ocorre, pajés e rezadores kamaiurá percorrem os caminhos, a área que cerca a casa dos homens, as moitas em buscas de eventuais feitiços deixados pelos convidados e com gestos e orações livram os lutadores de uma possível derrota encomendada. Nos acampamentos, cuidado igual é tomado, cheirando-se a comida oferecida para detectar o cheiro dos charutos dos pajés, indício de que foi "rezada", isto é, alvo da ação das rezas (monaré orepeiu). A desconfiança é generalizada em praticamente todas as cerimônias. Mesmo os pajés quando vão fazer cura em outra aldeia costumam levar seus próprios charutos já enrolados, evitando aceitar os oferecidos pelos líderes da aldeia. Inclusive os alimentos são discretamente cheirados. 
Poucas horas antes do amanhecer as famílias enlutadas param de chorar e seguem para descansar, pois a alma do morto já abandonou o tronco em direção à aldeia dos mortos. Nos acampamentos, peixe e beiju e mesmo, algumas vezes, café preto em grandes garrafas térmicas são levados aos convidados pelo respectivo pareat. Ninguém dorme. A noite passa em meio a brincadeiras e zombarias com vizinhos de acampamento, uma vez que o lutador não pode dormir, temendo um sonho aziago que prenuncie sua derrota. A algazarra se prolonga até o amanhecer.

Logo cedo, os visitantes são levados até ao pátio da aldeia pelo seu pareat. Os caciques são acomodados em bancos e cada grupo com a respectiva bagagem se acomoda atrás deles. As flautas uruá são tocadas e os lutadores kamaiurá dão uma volta no pátio exibindo-se no ho'at, o mesmo fazendo os lutadores das aldeias convidadas, para finalmente postarem-se atrás dos seus líderes. A grande competição está para começar. O "dono da festa" passa a chamar, um a um, os melhores lutadores kamaiurá, que seguem até o meio do pátio e com joelhos e mãos no chão olham em direção ao povo desafiado. Os adversários são convocados por seu próprio líder e se postam na mesma posição, a pequena distância dos lutadores da aldeia. Tem início a luta huka huka, assemelhada a uma luta livre durante a qual vence quem conseguir tocar a parte de trás do joelho do adversário. Quando dois grandes lutadores se enfrentam há um jogo de força impressionante, ambos praticamente sem se mover, com musculatura exuberante, cada qual tentando desequilibrar o outro. Durante a festa do Kwaryp, os kamaiurá lutam contra os melhores lutadores das aldeias convidadas. Lutadores de menor destaque entram em seguida na arena e, ao final, meninos desafiam seus opositores.

No encerramento da grande festa, tocadores de uruá das diferentes aldeias se exibem e finalmente tocadores kamaiurá selam o término da exibição. Resta ainda um último ritual protagonizado por uma jovem que se encontra em reclusão pubertária e entra no pátio acompanhada da mãe. A menina-moça com a pele muito clara, pernas inchadas pelo uso continuado de amarrilhos de algodão nos tornozelos e abaixo dos joelhos, com a franja dos cabelos cobrindolhe os olhos, recebe do "dono da festa" castanhas de pequi. Ela segue em direção aos convidados e se detém diante do primeiro grupo, oferecendo ao líder um punhado de castanha. Ele retira da perna da moça o tradicional cinto de algodão usado por homens (kwahap) que ela traz preso no joelho e guarda para si. A mãe coloca outro cinto na perna da jovem que caminha em direção ao grupo seguinte de visitantes onde a mesma cena se repete. Dizem que na aldeia de cada povo, a castanha é triturada, misturada ao pirão de peixe e distribuída aos moradores.

É oportuno registrar que a grande festa do Kwaryp termina com a luta entre convidados e anfitriões que serve para expor o preparo dos atletas, eleger campeões e deixar fluir, de forma controlada, a animosidade recíproca que os diferentes povos alimentam. A competição do huka huka é também uma 
exibição da força do homem que neste final das comemorações é um claro símbolo da masculinidade, alinhado à bela figura da jovem reclusa, expressão da fecundidade feminina. Os dois símbolos se completam numa alegoria ao prosseguimento da vida e da comunidade.

Um pequeno detalhe exige explicação: o discreto gesto da jovem reclusa ao distribuir castanha de pequi aos líderes das aldeias convidadas. Qual seria seu significado? Foi necessário buscar na mitologia kamaiurá elementos que lançassem luz ao singelo ritual. Localizei um mito nos apontamentos de campo, da primeira década de 1970, registrado com o seguinte título: Waitsoyt, esposo de Kwiawiru e Kuñatin ${ }^{7}$. O mito foi narrado por Takumã Kamaiurá, grande pajé e então líder da aldeia de Ipavu, e relata a origem do pequi. A narrativa completa foi anexada no final deste texto, citando-se aqui apenas os principais acontecimentos contidos nessa versão, que servirão de apoio à minha hipótese sobre o que significa a distribuição de castanha.

As duas irmãs, esposas de Waitsoyt, Kwiawiru e Kuñatin foram à roça e no caminho viram um rapaz bonito, muito enfeitado. Perguntaram: quem é você? Ele respondeu sou o jacaré e vim aqui namorar vocês. Eles se abraçaram e em seguida ele e uma delas foram para o mato namorar; mais tarde foi a outra. Despediram-se, prometendo se encontrar no dia seguinte. Na manhã seguinte as moças fizeram beiju e levaram mohet para o encontro com o jacaré, a quem confessam: agora você já é nosso marido. E assim continuaram por um bom tempo.

Um dia Waitsoyt, o marido delas, foi caçar, viu uma cutia e retesou o arco para flechá-la. A cutia então disse: porque você quer me matar, não sou eu que estou namorando suas mulheres! Em seguida, levou-o ao local onde o jacaré e suas esposas namoravam. Waitsoyt construiu uma pequena plataforma numa árvore, de onde pretendia constatar o encontro dos amantes.

No dia seguinte, o jacaré encontrou as moças e relatou a elas que havia sonhado que o marido delas iria mata-lo. Se isso acontecer, vocês tirem a flecha e a rachem no meio, façam fogo, queimem meu corpo e depois enterrem as cinzas.

No outro dia, os amantes se encontraram sem suspeitar que Waitsoyt os

\footnotetext{
${ }^{7}$ Outras versões do mesmo mito foram registradas por Samain (1980:152-171) e Villas Bôas (1970: 162-166).
} 
observava em cima da árvore. Depois que o jacaré namorou as duas, o maridoflechou-o. Em seguida bateu nas mulheres e falou que não precisavam voltar para casa. As moças choraram muito a morte do namorado e com o sol alto, uma delas lembrou-se das recomendações do jacaré, então pegaram lenha e queimaram o corpo. No dia seguinte, enterraram as cinzas que em pouco tempo começou a brotar, era pé de pequi que estava nascendo. Uma das irmãs lembrou que o jacaré havia dito: do meu saco vai nascer o pequi, dos dentes, o pé de pimenta pequena e pimenta grande, da cabeça o pé de cabaça, dos olhos, a frutinha muhun. O pé de pequi cresceu rapidamente. Certo dia, apareceu por lá o papagaio de Kwat, pegou um pequi e saiu voando. Não mexa com ele não, disse uma das mulheres, pode ser o filho de Kwat. De fato, o papagaio voou para Morená com o caroço do pequi no bico. Entrou em casa e soltou o caroço. Kwat falou: é de pequi! Disse então para o papagaio: vamos lá, você vai voando e eu e Iay vamos pelo caminho (Kwat= Sol e Iay= Lua, gêmeos míticos, netos de Mavutsinin).

Chegaram na casa das duas moças e pegaram um pequi maduro, cheiraram e constataram que não tinha cheiro. Disseram para as irmãs: vocês tem cheiro gostoso na vagina, passem o pequi lá para que seu marido não vá sentir esse cheiro bom em outra mulher e ficar atraído. As moças passaram o pequi na vagina, puseram o caroço na casca. Kwat abriu e cheirou falando: agora está bom. Em seguida Kwat pegou formiga fedegosa (taitaren) esmagou bem e mandou que passassem na vagina. Depois Kwat as ensinou a cozinhar o pequi e fazer tukumaiá, sopa de tapiok. Assim nossos netos vão fazer. Os gêmeos ficaram lá algum tempo comendo pequi e talvez namorando as jovens. Como o pequizeiro estava muito carregado, Kwat bateu com o pé no tronco e caiu muito pequi. Agora está bom. Assim não fica muito pequi. E o pequi só vai dar na época de pequi, não fica dando o ano todo.

Os acontecimentos do mito ocorrem num tempo remoto, quando os seres humanos se relacionavam diretamente com os heróis culturais, com os espíritos e os animais. Kwiawiru e Kuñatin eram protótipos da mulher indígena, ainda em construção. A cultura kamaiurá ampliava sua culinária e a própria natureza ainda estava sendo aprimorada e iria ganhar novas plantas, alguns animais e lagoas. 
A origem do pequi está diretamente ligada ao encontro secreto dos amantes que apaixonados vivem um amor proibido. Do sacrifício do jacaré-homem cujas cinzas são enterradas pelas duas moças nasce o pequi, a pimenta, a cabaça e a frutinha muhun. Se do corpo do jacaré criou-se o pequi, foi do corpo das moças que veio odor agradável da fruta. Assim o pequi foi criação conjunta dos amantes.

Os encontros amorosos com o jacaré eram cercados de desejo e prazer. Embora as moças tenham confessado "agora você é nosso marido", não havia por parte deles nenhuma intenção de formar uma família. "Você é nosso marido" poderia muito bem apenas significar "somos suas". Tratava-se de um amor despojado dos compromissos matrimoniais, voltado para viver uma paixão e que se distanciava das figuras emblemáticas do lutador de huka huka e da jovem reclusa, símbolos da continuidade da vida, da reprodução humana.

$\mathrm{Na}$ mitologia kamaiurá o casamento entre humanos e espécies animais ou seres sobrenaturais ocorre geralmente para explicar a aquisição de um bem cultural; o casal passa a viver junto, o casamento tem pouca duração e se desfaz por força da incompatibilidade nas relações familiares. O caso do jacaré, amante, e das duas moças é diferente pois resulta também na criação do pequi e no enriquecimento da culinária, mas a finalidade dos encontros centrava-se simplesmente no prazer.

Resta saber o que significa a castanha de pequi distribuída aos líderes visitantes?

Minha hipótese, de caráter especulativo, é a seguinte: num gesto discreto, como convém ao relato de aventuras amorosas clandestinas, evita-se a plena explicitação do símbolo proibido. Para transpor a barreira da interdição o recurso usado foi fazer vir à tona uma metáfora do amor sensual, a castanha de pequi, reservando-se para o grande final do Kwaryp o rito da sua distribuição, como uma alegoria à alegria de viver a vida.

\section{Referências}

Agostinho, Pedro. 1974. Kwarì, mito e ritual no Alto Xingu. São Paulo: EPU. 1974. Mitos e outras narrativas. Universidade Federal da Bahia, Coleção Ciência e Homem, Bahia.

Junqueira, Carmen e Vaneska Taciana Vitti. 2009. "O Kwaryp kamaiurá na aldeia de Ipavu”. Estudos Avançados 23(65), pp.133-147, jan./abr. 2009. Universidade de São Paulo.

Mauss, Marcel. 1974. "Ensaio sobre a dádiva. Forma e razão da troca nas sociedades arcaicas". In: Claude Lévi-Strauss. Sociologia e Antropologia, com uma introdução à obra de Marcel Mauss, tradução de Lamberto Puccinelli. São Paulo, EPU, pp.37184.

Samain, Etienne. 1980. De um caminho para outro. Mitos e aspectos da realidade 
social nos índios Kamayurá (Alto Xingu), dissertação de Mestrado apresentada ao Programa de Pós-Graduação em Antropologia social do Museu Nacional da Universidade Federal do Rio de Janeiro, volume II.

Seki, Lucy. 2010. Jene Ramyjwena Juru Pytsaret. O que habitava a boca de nossos ancestrais. Rio de Janeiro: Museu do Índio.

Villas Bôas, Orlando. 2000. Kuarup. A lenda da criação. In: O. Villas Bôas. A arte dos pajés. São Paulo: Globo.

Villas Bôas, Orlando e Claudio. 1970. Xingu. Os índios, seus mitos. Rio de Janeiro: Zahar.

. 1986. Xingu. Os contos do tamoin. São Paulo: Kuarup. 1992. Xingu. Histórias de índios e sertanejos. Porto Alegre: Kuarup.

Würker, Estela; Maria Cristina Troncarelli (orgs.). 2005. Memórias de tempos antigos: livro de mitos dos povos indígenas do Xingu. São Paulo, ATIX/ ISA.

\section{ANEXO}

\section{Waitsoyt, esposo de Kwiawiru e Kuñatin}

As duas esposas de Waitsoyt foram à roça e no caminho viram um rapaz bonito, enfeitado com colar, brinco e cinto. Quem será, perguntaram entre si? Sorriram para ele à medida que se aproximavam e então perguntaram: quem é você, o que está fazendo aqui? Ele respondeu: eu sou o jacaré. Vim aqui para namorar vocês! Eles se abraçaram, pois estavam se gostando. Em seguida, ele e uma delas foram para o mato namorar; depois foi a outra. Antes de se despedirem Kwiawiru falou: amanhã vou trazer beiju para você e Kuñatin vai trazer mohet. Foram então para a beira da lagoa e ele falou: amanhã venho encontrar vocês de novo aqui; transformou-se em jacaré e desapareceu nas águas. As duas mulheres contentes foram tirar mandioca e então voltaram para a aldeia. Uma delas disse: não vá contar para ninguém, senão nosso marido vai acabar sabendo. Chegaram em casa, ralaram a mandioca que haviam tirado, felizes da vida. De madrugada, quando o galo cantou, uma das mulheres falou para a outra: vá fazer beiju para a gente levar para comer. Pegue também mohet para a gente tomar. Chegando no caminho da roça elas chamaram: vem cá jacaré, venha comer beiju e tomar mohet! Em pouco tempo ele apareceu nadando, saiu d'água e virou gente. Comeram, conversaram e as duas mulheres falaram: agora você já é nosso marido. Brincaram, se abraçaram e depois uma e em seguida a outra foram namorar no mato. 
As coisas continuaram assim, as mulheres todas as manhãs indo namorar o jacaré, sem que o marido nada soubesse. Certo dia, o marido saiu para caçar. Avistou uma cutia, retesou o arco para flechá-la e, estava prestes a atirar, quando a cutia falou: não me mate não meu neto, pois eu não namoro suas mulheres! $\mathrm{O}$ jacaré é que está namorando elas. Waitsoyt ficou surpreso! A cutia então levou-o onde o jacaré e suas esposas comiam beiju e tomavam mohet: aqui eles comem e bebem. Aqui é onde ele namora uma, aqui é onde namora a outra. E continuou: você pode amarrar pau aqui nessa árvore e ficar vendo tudo.

No dia seguinte, as mulheres foram como sempre. O jacaré veio e lhes contou: eu sonhei que seu marido vai me matar. Se ele me matar, vocês tirem a flecha e a rachem no meio, façam fogo, queimem meu corpo e depois enterrem as cinzas. Ao final do encontro, as duas cataram mandioca e voltaram para casa. No dia seguinte, o marido saiu rapidamente assim que as duas saíram para a roça. Armou um jirau perto do local onde elas encontravam o jacaré, voltando para casa antes delas. Quando elas voltaram o marido falou: vocês estão tão contentes, acho que estão fazendo alguma coisa! Uma delas convidou a outra para banhar e o marido não quis ir. Longe dele, elas se olharam e uma delas disse: você viu como o homem falou? Acho que alguém contou para ele! Voltaram para a casa e viram o marido fazendo ponta de flecha. Por que você está fazendo isso, uma perguntou? É que amanhã vou caçar. No dia seguinte de madrugada o marido saiu. Onde você vai caçar? Vou no mato, vou pescar também, vou de canoa, mentiu ele. Mais tarde, as mulheres fizeram beiju, pegaram mohet $\mathrm{e}$ foram para a roça. Comeram e beberam junto com o jacaré. O marido na árvore, nervoso, viu o jacaré namorar uma, depois a outra. Vovô tinha razão! Quando acabou o namoro e a mulher sai do colo do jacaré, ele o flechou. Desceu e as mulheres indignadas falaram: por que você fez isso? Ele ainda flechou muitas vezes o jacaré. Em seguida, pegou um pau e bateu na mulher até ela desmaiar. Depois foi a vez da outra. Ao final Waitsoyt falou: vocês não precisam mais voltar para casa.

As mulheres ficaram desoladas, chorando. Com o sol alto, uma delas perguntou: como o jacaré disse para fazermos? Ele disse para tirar a flecha do corpo dele, racha-la, com isso fazer fogo e queimar seu corpo. Pegaram lenha, fizeram fogo e puseram o corpo na fogueira e mais lenha por cima do corpo. Queimaram tudo. Mais tarde, seu irmão, preocupado com a demora, foi até lá para ver o que tinha acontecido. Encontrou as duas tristes. O que foi, perguntou? O marido bateu na gente! Por que? Não sabemos. Vocês não fizeram coisa errada, namoraram? Não, não fizemos nada. Não vamos voltar para a aldeia. Não, não queremos mais voltar, vamos ficar por aqui mesmo. Então vou buscar a rede de vocês, disse o irmão. Foi e como o marido não estava mais na 
casa, pois já tinha ido para a casa dos seus parentes, ele pegou as reder e levou para as irmãs. Lá chegando, ele limpou o terreno para elas e armou as redes, voltando então para a aldeia.

No dia seguinte, elas enterraram as cinzas do jacaré. Em poucos dias começou a brotar, era pé de pequi que estava nascendo. Uma das irmãs lembrou que o jacaré havia dito: do meu saco vai nascer o pequi, dos dentes, o pé de pimenta pequena e pimenta grande, da cabeça o pé de cabaça, dos olhos a frutinha muhun. O pé de pequi cresceu rapidamente.

Apareceu por lá o papagaio de Kwat e pegou um pequi e saiu voando e comendo. Olha um papagaio, disse uma das mulheres. Não mexa com ele não, pode ser filho de Kwat. De fato, o papagaio voou para Morená com o caroço do pequi no bico. Entrou em casa e soltou o caroço. Kwat falou: é de pequi! Disse para o papagaio: vamos lá, você vai voando e eu e Iay vamos pelo caminho. Quando as mulheres viram Murenajat (moradores de Morená) uma delas falou não conta nada para Kwat, senão ele pode fazer alguma coisa conosco. Mas assim que os irmãos chegaram, Kwat falou: então seu marido matou o jacaré que vocês estavam namorando? Kwat já sabia de tudo! Saíram então da casa e foram onde estava o pé de pequi. Kwat perguntou para Iay: o que é? Iay respondeu é pequi. Pegaram um pequi maduro, cheiraram e não tinha cheiro. Chamaram as duas irmãs e disseram: vocês têm cheiro gostoso na vagina, passa o pequi lá para que seu marido não vá sentir esse cheiro bom em outra mulher e ficar atraído. Dizendo isso, ele tirou o caroço do pequi, deu para as mulheres e saiu. As jovens, cada uma por sua vez, passaram o pequi na vagina e por fim puseram-no na casca. Chamaram Kwat que abriu e cheirou o pequi, falando está bom! Em seguida, Kwat pegou formiga fedegosa (taitaren), esmagou bem e disse para as mulheres: agora vocês passem isso na vagina. Depois Kwat ensinou-as a cozinhar o pequi e a fazer tukumaiá, sopa de tapiok. Assim, nossos netos vão fazer. Kwat ficou algum tempo lá comendo pequi e talvez namorando também. Como o pequizeiro estava muito carregado, Kwat bateu com o pé no tronco e caiu muito pequi. Agora está bom. Assim não fica muito pequi. E o pequi só vai dar na época de pequi, não fica dando o ano todo, não.

Os dois irmãos voltaram para Morená, levando bastante pequi e lá mostraram para Mavutsinin: o que é isso vovô? Isso é pequi, respondeu ele. Mavutsinin sabia que era pequi. Chamaram as esposas e pediram para cozinhar o pequi e fazer pekeiau, creme de pequi cozido para misturar com peixe (pekeiapin).

Mais tarde, apareceu a arara lá nas mulheres do pequi. Entrou, comeu pequi e ficou morando um pouco com elas e namorando. Veio depois o periquito, que também ficou lá algum tempo namorando as mulheres. E o mesmo aconteceu com vários outros pássaros da família dos periquitos e araras. Quando a cutia 
apareceu, elas a reconheceram e disseram: entre vovô nós não temos comida para lhe dar. A cutia foi embora. Mais tarde, a família das duas mulheres foi morar com elas".

Data recebimento: $12 / 04 / 2015$

Data aceite: $15 / 07 / 2015$ 